\title{
Overturned Time and Space: Drastic Changes in the Daily Lives of North Koreans during the Korean War
}

\author{
Taewoo Kim
}

\begin{abstract}
This article analyzes the overturning of time and space in the daily lives of North Koreans during the Korean War. The overturning was caused by the aerial bombings by the United States Air Force that lasted for three years. In particular, after the execution of the scorched earth policy, in November 1950, which destroyed all the cities and villages in North Korea, most people lost their dwellings and had to endure living underground, in dugouts or mud-huts; they were also mobilized at night to restore industries and transportation facilities. This article describes the miserable daily lives of North Korean civilians during the war, a topic that has rarely been discussed, and explains how this experience continues to affect the worldview of the North Korean people.
\end{abstract}

Keywords Korean War, North Korea, daily life, USAF, bombing, wartime restoration

\section{Introduction}

The Korean War lasted for three years (1950-1953) and completely overturned the daily lives of the Korean people. It was all too obvious to Koreans in both South and North that they could not live the ordinary lives that they had enjoyed before the war. All social goals and activities were reoriented for the attainment of the national goal-winning the war. Individuals were forced to sacrifice themselves for their country in national wartime mobilization.

However, the daily lives of South Koreans, who were located primarily in the rear area during the war, were relatively calm and peaceful compared to the lives of North Koreans. ${ }^{1}$ In particular, after the front was stabilized near the present Military Demarcation Line in the middle of 1951 and armistice negotiations began in earnest, most parts of South Korea-except the front and a few isolated guerrilla areas-were quite free from the destruction of the war. During this 
time North Koreans experienced completely different daily lives. In North Korea, from immediately after the outbreak of the war to the finalization of the armistice negotiations, there was no actual rear area. Throughout the war that dragged on throughout the long armistice negotiations the most important goal for ordinary North Koreans was only survival.

Aerial bombing in North Korea by the United States Air Force (USAF) was the most crucial cause of the difference in everyday life between North and South Koreans. The United States had directly intervened immediately after the outbreak of the war, on June 25, 1950, and started air strikes in North Korea with the bombing of the airfield near Pyongyang, the North Korean capital, on June 29. The United States continued bombing North Korea every day for three years, until the armistice agreement came into effect at 10 p.m. on July 27, 1953. During the early months of the war the USAF tried to follow a policy of precision strategic bombing targeting only military targets. However, most of the military targets in the earlier part of the war were located in densely populated urban areas, and the accuracy rate of the U.S. strategic bombers was noticeably low, so that adhering to the precision bombing policy was practically impossible. Furthermore, Douglas MacArthur, the United Nations Forces Commander, officially initiated, on November 5, 1950, the destructive "scorched earth policy," which designated all the cities and villages in North Korea as military targets of the USAF bombers. This decision was made as the UN ground forces were forced to give up territory in the face of assaults by the newly appeared enemy, the Chinese People's Volunteer Army (PVA). Until the end of the war, even wholly civilian areas in North Korea were regarded as justifiable military targets that could be destroyed at any time, and all of the cities in the North were reduced to rubble (T. Kim 2012b).

The daily lives of North Koreans living among the ruins were never the same following the outbreak of the war. Aerial bombing caused the destruction of the basic necessities of life. It also made North Koreans conscious of the crisis state of their everyday lives, as they had to find a way to survive in the face of indiscriminate air strikes by the USAF. The North Korean government diligently established relief policies for war refugees, but the destruction was so widespread that there was a clear limit to what could be done.

This article explores the daily lives of North Koreans during the Korean War, a topic that has rarely been discussed in the literature. Surprisingly enough, it is hard to find previous studies specifically analyzing this issue. Recently, Han's research paid attention to the process of forming the concept of inmin (the people $)^{2}$ as a unique identity of North Koreans forged through the Korean War, but surprisingly his study did not include examination of the everyday lives of North Koreans during the war (Han 2012a; 2012b). Perhaps the lack of sociohistorical data documenting the wartime daily lives of North Koreans is the most important reason for the absence of such a research focus in previous studies. 
Furthermore, we need to pay attention to the fact that the view regarding North Koreans as victims of the war has been strictly forbidden in South Korea due to the deep antagonism between North and South following the war. Given the antagonistic cold-war relationship, North Korea had to be viewed as the "aggressor" at all times. In this political and social atmosphere, it has not been an easy task to perform an objective analysis of the daily lives of North Koreans or an analysis viewing them as victims.

This study aims to analyze the phenomenon of the overturning of the daily lives of North Koreans due to air strikes by the USAF by comparing North Korean army documents captured by the U.S. Army in occupied territory, intelligence reports by the USAF, and documents from the Soviet Union and China. Aerial bombings during the war led to differentiation in the lives of South Koreans and North Koreans. Bombings had a deep effect on the time, space, and thought of North Koreans and radically overturned their daily lives. Furthermore, the overturning of the daily lives of North Koreans during the Korean War still has a major impact on the daily lives and thinking of contemporary North Koreans.

\section{Overturned Space: Underground Living}

The outbreak of a war naturally causes huge shock and fear for civilians caught in a battlefield. Many civilians, uprooted from their long-time living arrangement, flee for survival to avoid the flames of war. Distortion and desertion from one's daily living space during wartime is not unusual. The distortion of the space of daily life was not limited to South Korea, where the South Korean and North Korean armies violently collided in the early months of the war. During the same period, the evacuation of civilians likewise occurred in North Korea, though the cities and villages were far from the early battlefields in the South.

Before the outbreak of the Korean War, the North Korean leadership evaluated the probability of U.S. participation in the war to be low. Kim Il Sung, the North Korean leader, and his entourage stayed in Moscow for a month in April 1950 and met with Stalin three times before the outbreak of the war. Kim contended that the United States was not foolish enough to intervene because North Korea had forged an alliance with the Soviet Union and China (Torkunov 2003, 112-113). Kim Il Sung seemed sure that the United States would not directly intervene in the Korean Peninsula because the U.S. had not dispatched an army to China during the Chinese Civil War (1946-1949). This poor evaluation by the North Korean leadership of the possibility of U.S. intervention was confirmed by the lack of an air-defence policy in the North right after the outbreak of the war. Once the USAF started bombing North Korea, Kim Il Sung and other North Korean leaders-including Kim Du Bong, Kim Dal Hyun, and Pak Hon Yongwere shocked and flustered (Shtykov 1950). Government officials, members 
of the Korean Workers Party (KWP), and a lot of civilians in cities lost their sense of judgment, were confused, and were left without practical and concrete alternatives.

When bombings began the first phenomenon was the disorganized dispersion and evacuation of the urban population. For example, dozens of governmental institutions and members of social organizations in Wonsan, one of the major industrial cities on the east coast of North Korea, continually urged citizens to disperse. In addition, party officials in Nampo, an industrial city on the west coast, officially decided upon and issued orders for the evacuation of citizens. Some of the party officials in Nampo deserted their posts in advance, relinquishing their responsibilities, and some staff members of Home Affairs (Naemuseo) in Wonsan even threatened and banished citizens who had sought shelter in the designated safe zone. They neglected wartime responsibilities of extinguishing fires and transporting staple supplies. In addition, the production rate and worker attendance rate of major industrial facilities dramatically decreased; for example, the attendance rate of the Wonsan car factory was $11.5 \%$ and the rate of the Nampo smelter was only 21\%. Most of the citizens of Wonsan and Nampo chaotically escaped to the countryside, and they ate and slept in the open to avoid the air strikes (KWP 1950). The first spatial distortion occurring immediately after the outbreak of the war was "desertion" from the past ordinary space.

Desertion from their daily life space could temporarily protect civilians' lives. But civilians could not continue camping in the mountains and the outskirts of the cities throughout the war that, as far as anyone knew, could last anywhere from several months to several years. In particular, a temporary shelter with a simple awning but lacking a firm residential space might be feasible in the summer (June-August), but simple camping could not be enough to protect the evacuees with the change of season and the onset of the harsh Korean winter. Furthermore, after setting all the cities and farm villages in North Korea as military targets in November 1950, the USAF started to burn even individual private houses in the deep mountains using incendiary bombs, which had shown their destructive power in World War II. As a result, North Koreans were suddenly and completely exposed to bitter cold-from 20 to 30 degrees below zero centigrade. The North Korean leadership had to solve the housing problems threatening the survival of the civilian population.

The solution for the housing problem suggested by the North Korean leadership in November 1950 was the construction of "dugouts" or "mud-huts." Dugouts or mud-huts meant temporary dwellings that could provide protection from the cold or storms constructed by digging an underground tunnel and covering it up with straw matting or dirt. The North Korean leadership, in fact, commanded the people to dig into the ground under the ruined cities and live in underground tunnels to survive the bitter cold and bombing. They instructed 
the civilians to "build dugouts or mud-huts in a proper place by late November," but a concrete measure for actualization of the plan suggested by the government merely mentioned the following: "Take action to guarantee the supply of materials such as wood needed for building dugouts or mud-huts" (DPRK 1950).

The underground living conditions of civilians in North Korea from late 1950 to early 1951, when the scorched earth policy was executed by the USAF, was clearly shown in the report of the investigation team of the Women's International Democratic Federation (WIDF). ${ }^{3}$ The investigation team, called the Women's International Commission for the Investigation of War Atrocities Committed in Korea (WICIWAK), conducted an on-site survey at the time of the war and made a vivid record of conditions and war damage. The investigation team sent to North Korea during the war was composed of 20 representatives from 18 countries in Europe, the Americas, Asia, and Africa, plus one observer. The team leader was Nora Rodd, a Canadian. Between May 16 and 27, 1951, the team visited several cities and villages, including Pyongyang, Sinuiju, Nampo, Wonsan and Haeju (WICIWAK 1951, 5).

The city that the investigation team first visited was Sinuiju, located in the border area between North Korea and China in the northwestern region of the Korean Peninsula. The team described the lives of the citizens of Sinuiju, a city destroyed by bombing, as follows:

The overwhelming majority of the inhabitants live in dug-outs made of earth supported with salvaged timber. Some of these dug-outs have roofs made of tiles and timber, salvaged from destroyed buildings. Others are living in cellars that remained after the bombardment and still others in thatched tents with the frame-work of destroyed buildings and in huts made of unmortared brick and rubble (ibid., 9-10).

The USAF scorched-earth policy brought devastation to a considerable portion of the civilian areas in North Korea. "The overwhelming majority of the inhabitants" in Sinuiju could only carry on with life while living in battered mud-huts. The investigation group visited one hut in person, that of Kwon Mun Su and his family. Kwon Mun Su lived with his wife and three children in a small hut divided into two rooms. One room was a kitchen measuring one-half by three meters, and the other room was a bedroom measuring three by two meters. Five family members lived in this small room measuring only six square meters. From the point of view of the investigation team members, daily life in that place was terrible. However, Kwon and his family were considered "lucky" and they were the envy of their neighbors. This was because they at least had a room to stay in and also one blanket, amenities that most other people did not have (ibid., 10).

As mentioned above, in November 1950, the North Korean government commanded citizens who had completely lost their residential space due to the USAF scorched earth bombing to build underground huts, such as those shown 
Figure 1. Woman and Child in the Entrance of a Mud-hut

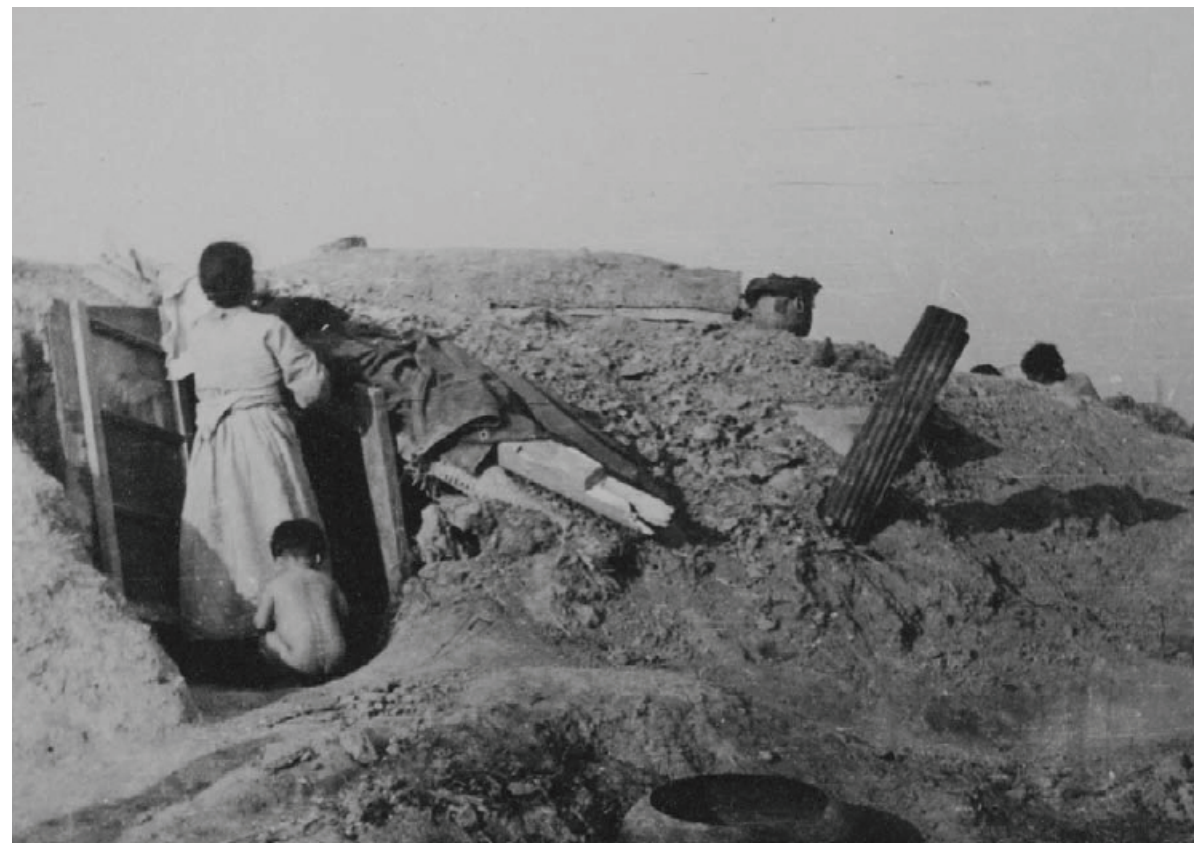

Source: Springer 2009, 31.

in Figure 1, for protection from air strikes and the cold. North Koreans were obliged to construct huts for survival because throughout the country it was practically impossible to engage in daily life while living in a house aboveground. However, as shown in Figure 1, huts might have been able to protect the lives of the inhabitants from cold in the middle of winter, but they could hardly protect them from air strikes. General-purpose and incendiary bombs dropped by the USAF could easily destroy and burn such roughly built houses.

The WIDF investigation team conducted interviews with the inhabitants of Pyongyang. The team, which was divided into four groups to inspect each downtown area, could not find any houses having walls or ceilings during their inspection. They visited several families, including the family of Kang Bok Sen. This family consisted of five members including a three-year-old child and an eight-month-old infant. They were living in the air-raid shelter of the destroyed Women's Federation office building, in a space that measured just one by two meters. Furthermore, the investigation team members had to crawl through a three-meter tunnel to enter the shelter. This small space was their sole living space. It was miraculous that five people, including two small children, were able to live in a small underground room measuring only two square meters.

Figure 2 vividly shows the weary daily lives of North Koreans living in 
Figure 2. Family in a Dugout Shelter

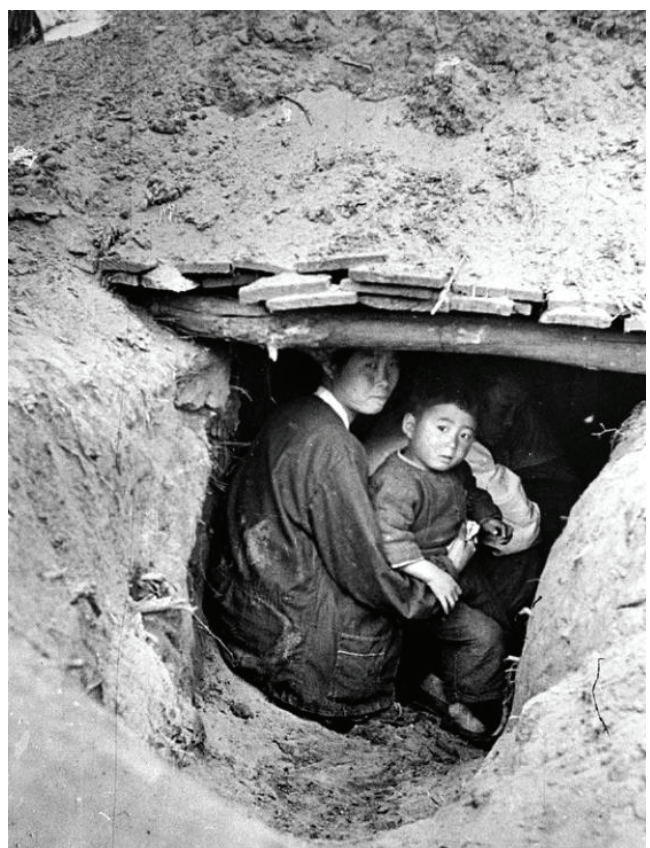

Source: Russian State Film and Photo Archive.

dugout shelters. Such a small dugout that a person could not move freely within was not a temporary shelter but a main living space. According to the WIDF research group, "The earth walls are too low to enable an adult to stand upright." In addition, "this shelter was typical rather than exceptional, and it would be possible to quote many more instances of families living in similar conditions" (WICIWAK 1951, 16).

The research team members lastly visited Kanggye and could see that "as in the other ruined cities, inhabitants live in holes in the ground." One family that the research group members visited in person was living in a basement of a destroyed building, and a 13-year-old child was taking care of his little brothers and sisters in the darkness. The youngest one was two years old. Their father, a railroad laborer, had been killed during a bombing of Kanggye by USAF planes on October 7 (ibid., 44-45). In this way, the war and bombings were threatening children's lives and rendering their daily lives completely unstable.

It can also be confirmed from North Korean investigation reports and newspaper articles that underground air-raid shelters in cities, and huts and holes at the foot of mountains were major living spaces until the end of the war. For example, the inhabitants in the residence zone in Pyongyang called Podowon (vineyard) were all living in huts, but the inhabitants as well as the 
huts disappeared after bombings on July 11, 1952 (Rodong Sinmun 1952a). The inhabitants "mostly living in the huts in the ruined" west and north zones in Pyongyang were also affected "with the destruction and disappearance of many houses and huts" due to the mass bombing on August 20 (Rodong Sinmun 1952b). In Wonsan, on September 17, 1952, "a great number of huts" were destroyed due to air strikes and bombardment from a warship (Rodong Sinmun 1952d). In Chongjin, on November 17, 1952, many huts were destroyed due to "approximately 190 bombings of hut zones in the city and farm areas." In Kanggye, on November 19, "dispersed civilian huts" in the target area were destroyed by approximately 90 bombing and strafing attacks (Rodong Sinmun 1952e). At that time, Rodong Sinmun, an official organ of the Korean Workers Party, denounced the USAF for air strikes continuing night and day "with the aim of destroying the few huts and inhabitants remaining in the ruined city" (Rodong Sinmun 1952c).

Beginning in July 1952, the number of North Korean newspaper articles related to the destruction of civilian hut areas greatly increased, and this was not coincidental. It directly reflected the development of the "air pressure strategy" by the U.S. Air Force that was launched in the same month. The United States aimed to increase pressure on the North Korean side at the armistice negotiations that were taking place at that time. The negotiations were deadlocked over the issue of prisoner exchange and the United States sought to break the deadlock by the overwhelming use of air power and bombing of civilian areas in North Korea. The key leaders of the U.S. Air Force who planned this strategy contended that buildings and inhabitants in the villages and the cities should be major targets. According to their report, "Killing considerable number of them [rear area troops and civilian laborers] would hurt the enemy, even though his manpower supply is vast ... These [buildings in cities and villages] should be considered as targets since they frequently provide concealment for supplies and shelter for troops and laborers" (Randolph and Mayo 1952, 12-13).

In planning the air pressure strategy in 1952, the United States paid particular attention to North Korean hydroelectric power plants as priority targets in order to exert psychological pressure on the North Korean leadership and people. The hydroelectric power plants in Supung, Pujon, Changjin, Hochon, Puyong and Mt. Kumgang were top-class facilities built by Japanese technical experts over a period of more than 20 years during the Japanese colonial period. These plants generated more than $90 \%$ of North Korea's electric power. In addition, the Supung power plant provided more than $10 \%$ of the power supply in Northeast China.

During the early part of the war the UN forces had excluded hydroelectric power plants from the list of strategic targets in North Korea. Military, economic, and political factors complexly affected the setting of this principle. First, the hydroelectric power plants were not production facilities, which were the key 
Figure 3. Wartime Underground Industrial Facilities (left), Wartime Underground Meeting of Members of the Korean Workers Party (right)
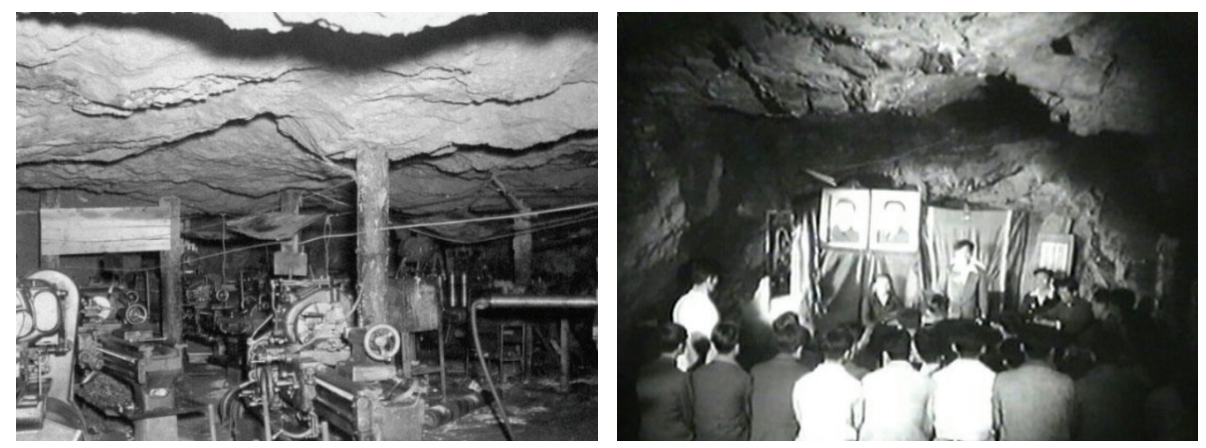

Source: National Archives of Korea.

strategic targets. And they were not easy to destroy completely because they were dispersed around the country. Furthermore, in the early months of the war, from the point of view of the UN forces that assumed the possibility of UN occupation of North Korea, electric power was critically important for recovery after the war, and the reconstruction of power plants would be costly. Furthermore, the Supung power plant supplied a considerable portion of electric power to Manchuria, and the UN forces did not want to provoke China during the early part of the war. However, when establishing the air pressure strategy in 1952, key leaders of the U.S. Air Force suddenly contended that the hydroelectric power plants were the most valuable targets in North Korea and the attack ban should be cancelled immediately (Randolph and Mayo 1952, 15).

The reason that the U.S. Air Force contended that the destruction of the hydroelectric power plants was the most effective way to psychologically suppress North Korea was directly related to North Koreans' underground living. USAF intelligence reports suggested that industrial facilities in North Korea were being reconstructed in underground facilities dispersed around the country. As shown in Figure 3, North Korea built major industrial facilities underground to avoid air strikes and continue production of supplies and weapons required for the war. Major social and political activities were also performed in the large underground tunnels. The USAF eventually realized that it was impossible to completely destroy these underground industrial facilities and that the destruction of the power source was more effective for military operations compared to the destruction of the industrial facilities. North Korean manufacturing facilities would be useless without electric power. The USAF actually started the bombing of the Supung power plant on June 23, 1952, and continued to attack the major hydroelectric power plants in North Korea for several months thereafter (Stewart 1957, 119-136). 
In this way, the three-year USAF bombing campaign during the Korean War displaced ordinary people in North Korea from their daily spaces. As a result, they moved from aboveground homes to underground dwellings, and major political and economic activities of North Korea were performed only in underground spaces. A considerable number of the inhabitants had to spend most of their time in small, dark huts. The only purpose there was survival. Can we guess the thoughts of the 13-year-old boy who had to take care of his sisters and brothers, including a two-year-old baby, in the small and dirty basement? How well can we understand North Korean civilians' hostility toward the United States, who had caused the deaths of their family members and the destruction of their mud huts in their already heavily ruined cities? War always makes a civilian's daily life in the rear areas of the front very tragic. But North Koreans had to endure even more horrible daily lives due to USAF air strikes during the three years of the Korean War.

\section{Overturned Time: Wartime Restoration Activities}

The overturning of the daily lives of North Koreans due to the bombings during the Korean War was also shown remarkably in the aspect of time, because the bombings completely reversed daytime and nighttime for a considerable number of people. It was not only the small underground tunnels that protected North Koreans from air strikes during the war but also the pitch-black darkness of the night that enabled civilians to work aboveground.

The overturning of many North Koreans' days and nights, induced by the bombings, started with the North Korean troops at the front during the early part of the war. In July 1950, as the tactical air operations of the USAF fighterbombers in South Korea dramatically increased, the military operations of the North Korean troops began to change drastically. In the early days of the war, the North Korean troops had continued to advance south, with direct attacks on the defensive positions of the South Korean armed forces. However, once the operations of the USAF in South Korea intensified, the North Korean troops started to use flank attacks, using roundabout ways and mountain road detours to besiege and isolate the resistance points of the South Koreans. In addition, many North Korean units moved only during the night in order to avoid daily tactical air strikes. All types of transportation for unit support were mobilized mainly during the night, and daytime maneuvers were undertaken only when rain or other inclement weather made bombing impossible (KIMH 2001, 194).

The U.S. Fifth Air Force's operational analysis team investigated the countermeasures used by North Korean troops in the face of USAF fighterbombers by interviewing North Korean troops captured in South Korea in 1950. Nine out of a total of 37 troops investigated (approximately one-fourth) testified 
that their units "travelled only at night" (FAF Operations Analysis Office 1951a). In August 1950, Pak Hyo Sam, the 9th infantry division commander of the North Korean troops, issued a "march-order" (haenggun myeonryeong) that told "troops to march mainly at night following a hard schedule after resting in the daytime" (Staff of the 315th Military Unit, 1950). U.S. air strikes during the early part of the war reversed the active hours from daytime to nighttime for the North Korean troops and also changed the pattern of ground battles.

During the same period of time, some North Koreans supporting the war effort behind the lines were also living with reversed days and nights. They were personnel participating in the reconstruction of industrial and transportation facilities destroyed by air strikes. Initially these people, temporarily assigned to reconstruction activities, worked around the clock rather than living with reversed days and nights. For example, in August 1950, laborers for electric power distribution, under the command of manager Jang Hong Nam, succeeded in restoring in a short period of time transmission lines and a substation destroyed by the bombing. They received essential assistance from a noryeok hyeopjodae (labor supply group), which was composed of approximately 3,000 farmers from nearby areas. They were engaged in restoration regardless of whether it was day or night; thus, transformer repairs, which usually took more than a month, were completed in just six days (Rodong Sinmun 1950b).

In this way, reconstruction activities in response to damage caused by wartime bombing focusing on major munitions and industrial facilities in North Korea during the early part of the war were sharply expanded after the middle of 1951 to include railroads, roads, and bridges throughout the country. The reason for this nationwide, major expansion of wartime restoration activities was directly related to the railroad interdiction campaign by the USAF, which began in the middle of 1951 and continued for a year. Studies on the history of USAF operations usually highlight this period of one year (June 1951-June 1952) after the beginning of armistice negotiations as the period of railroad interdiction (Futrell 1961, 400-438; Kohn and Harahan 1986; Mark 1994). During this period railroads in North Korea were some of the most important USAF targets. The communist forces (North Korean and Chinese) fighting at the front absolutely depended on food and weapons from China. If food and weapons were not supplied to the front, the communist forces would collapse immediately. In this situation, the rail system was regarded as one of the most important means of transportation for providing supplies.

Studies show that in North Korea today rail transportation accounts for $90 \%$ of total cargo transportation, while road transportation and maritime transportation account for only $7 \%$ and 3\%, respectively. In the case of passenger transportation, rail accounts for $62 \%$, and road transportation and maritime transportation account for $37 \%$ and $1 \%$, respectively (Suh 2008, 437). The origins of this absolute dependency on railroads for cargo and passenger transportation 
in North Korea can be traced to the extensive railroad investment policies of Japan during the colonial period.

In the 1930s, the Japanese Empire adopted the policy of using the northern part of the Korean Peninsula as a supply base, and rapidly implemented an extensive program of railroad construction in order to efficiently requisition the human and material resources of Korea. Japan planned comprehensive railroad construction for logistics and exploitation according to the Chosen Railway 12-year Plan (1927-1938). The construction of a large number of railroad lines in northern Korea was initiated according to this plan, such as the Domun line (Unggi-Donggwangjin, completed 1933), Hyesan line (SeongjinHyesan, completed 1937), Manpo line (Suncheon-Manpojin, completed 1939), Donghae line (Wonsan-Pohang, Ulsan-Busan, partially completed by 1940), and Pyeongwon line (Pyongyang-Kowon, completed 1941). The Japanese Empire constructed port-oriented as well as north-south railroad lines, considering military advantages (Park 2008, 298-301). As it turned out, these features could be effectively used not only by the Japanese army during the colonial period but also by North Korean forces during the Korean War.

In the early part of the war Kim Il Sung ordered the organization of the "wartime railroad restoration regiment" in response to the railroad interdiction strategy of the USAF. Kim consistently stressed the importance of railroad restoration: "We should make a rational wartime transportation organization and rapidly improve railroad transportation facilities, including locomotives and freight trains, in order to increase their availability.... Railroad laborers should exhibit the ability to guarantee transportation to the front and actively learn train operation methods suitable for wartime conditions to ensure the mobility of transportation" (I.S. Kim 1980a, 98).

Emphasis on railroad transportation by the North Korean leadership gave birth to many heroes from the early part of the war. For example, the standing committee of the Supreme People's Assembly of North Korea issued a government ordinance to award the National Flag 3rd Class, at that time the highest honor that could be awarded to labors, and the Meritorious Deed Medal to 29 laborers who had been deemed to have made a great contribution to wartime transportation. In related newspaper articles North Korea emphasized the dedication of Ri Byong Son, a railroad laborer, and $\mathrm{Kim} \mathrm{Gun} \mathrm{Su}$, a communications officer, in restoring railroad lines. Another article extolled the life-and-death train operation of Kang In Sop, an engineer, as a brilliant, heroic tale (Rodong Sinmun 1950a). As wartime train transportation began to emerge as a vital issue impacting the outcome of the war, the North Korean leadership consistently emphasized the dedication of laborers working in this sector.

On August 17, 1950, the North Korean Ministry of Industry issued an instruction, "Concerning Guarantee of Wartime Rail Freight Transport," to every enterprise officially designating items regarded as military supplies, and 
took urgent steps to forbid rail transportation for non-military goods. This list of military supplies included the raw materials and equipment of each business such as iron ore, anthracite, steel, and hardwood. "Not urgent or not important cargoes" were designated as subject to prohibition for train transport (Jung 1950).

An important factor behind this emphasis on train transportation was the relatively superior freightage capability of train transport as well as the extensive railroad network in North Korea. According to previous studies, the railroad capacity was 16.3 million tons and the cargo capacity was 3,405 million tonkilometers (tons of railroad cargo by the transport distance) in 1949. By another measure, the railroad transport capacity of North Korea right before the Korean War was 44,657 tons per day (Suh 2008, 442).

According to an intelligence report of the Eighth United States Army during the war, the North Korean troops and the Chinese military forces had 60 divisions of various types in the combat areas in Sariwon and southward, and each division required 40 tons of supplies daily. In other words, the North Korean and Chinese military forces required 2,400 tons of supplies every day. The loading capacity of one train car was 20 tons, whereas the loading capacity of one truck was only two tons. Therefore, 120 freight train cars could transport the daily supply requirement (FAF G-2 Eighth Army and A-2 1951). Considering the fact that the daily transported load of the North Korean railroad system exceeded 40,000 tons per day in 1949, supplies for troops in the front could be covered entirely by train transportation if rapid restoration was accomplished during the war. Therefore, the UN forces had no choice but to focus on the destruction of the North Korean railroad system since it directly affected the outcome of battles.

The USAF's Operation Strangle, lasting from August to December 1951, and Operation Saturate, lasting from March to May 1952, were typical examples of the U.S. railroad interdiction campaign during this period. For these operations the USAF developed new bombing techniques specifically for railroad interdiction (FAF Operations Analysis Office 1951b; FAF Deputy for Intelligence 1952b, 4548). Nevertheless, in the end the USAF had to admit the failure of its railroad interdiction campaign. The cutting-edge technology of the most powerful country in the world had succumbed to the manpower of one of Asia's newborn agricultural countries.

The North Korean leadership made a life-and-death bet during the war on railroad and bridge reconstruction. Kim Il Sung said: "If railroads and roads are destroyed due to bombings by enemy planes, we should mobilize the people to restore the railroads and roads in timely fashion for the prudential transportation of military supplies and rear supplies" (I.S. Kim 1980b, 22). Thus the North Korean leadership aggressively mobilized the population to overcome the USAF's railroad interdiction campaign.

Figure 4 illustrates railroad interdiction bombing by the USAF in 1951 as well as the critical but dangerous railroad restoration program of the North 
Figure 4. Railroad Interdiction by USAF showing North Korean Laborers, 1951.

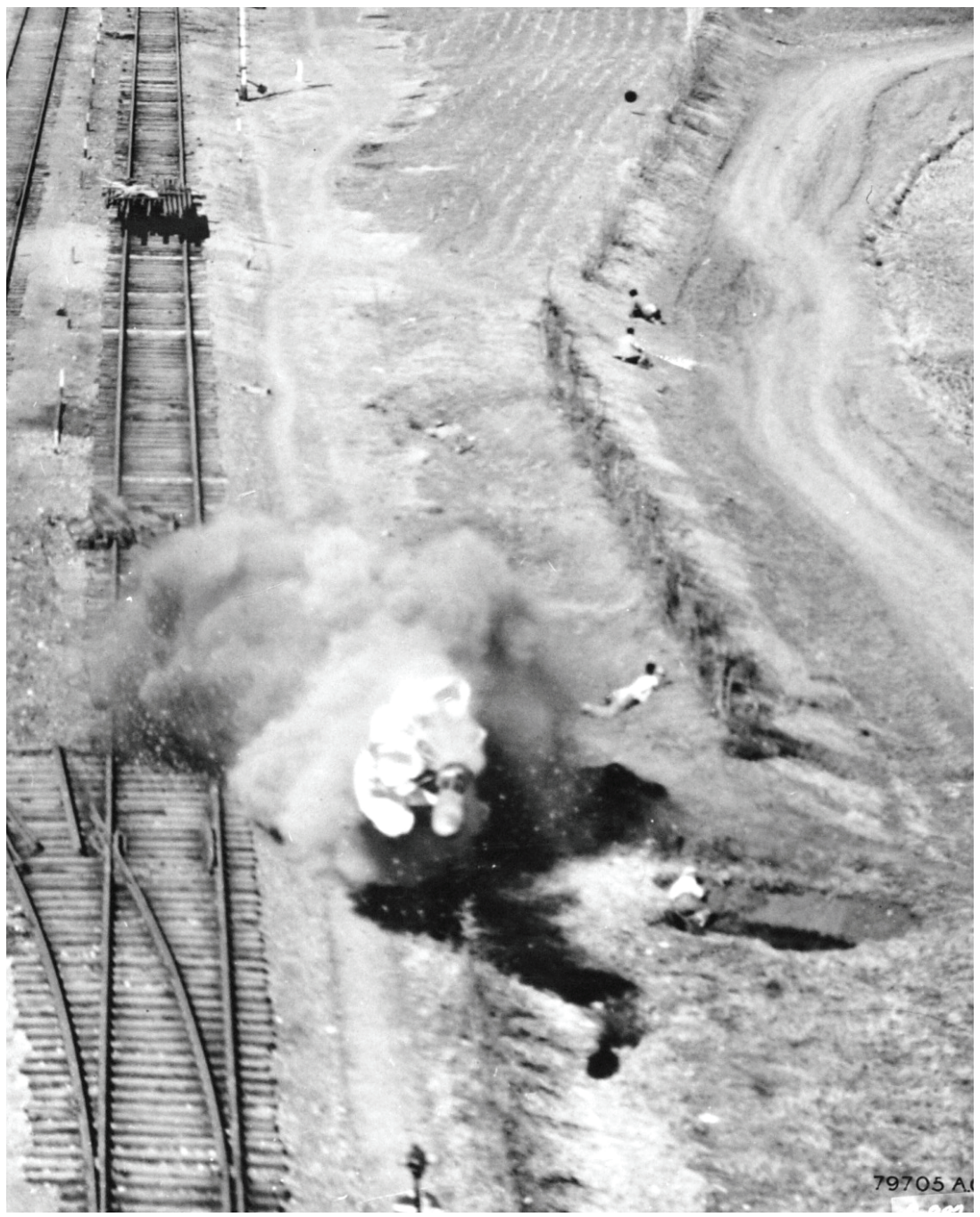

Source: FEAF1951.

Koreans. The photo was taken northwest of Pyongyang on April 7, 1951, and it shows the moment right before a parabomb drops onto the railroad. At least five people around the railroad are lying face down to avoid bomb shrapnel. The woman closest to the falling bomb is hiding in a bomb crater formed previously. The photo indicates that railroad restoration by North Koreans was actually a lifeand-death battle rather than ordinary forced labor (FEAF 1951).

The North Korean government needed to find a way to protect the lives of inhabitants near railroad lines, which were relatively densely populated 
areas throughout North Korea, and to mobilize them on a regular basis to the restoration projects. The optimal measure the government found was nighttime railroad restoration. Figure 4 shows the laborers accidently exposed in the daytime, but railroad restoration was mostly carried out at night. Those involved in railroad restoration projects fared no better than those engaged in actual battle against the bombing and darkness of the night. A USAF intelligence report describes the pattern of railroad restoration by North Korean laborers:

The enemy continued to demonstrate vast manpower resources in repair activities.... Intelligence sources have established, quite accurately, that major repair activities begin at dusk, and that from six to eight hours are usually required to repair a rail cut. Since it is also known that all repair activity is conducted simultaneously, it can be concluded that, on the average, a rail line can be used at most from midnight to sunrise. For example, between Sinanju and Pyongyang the enemy employs trackwalkers to spot rail cuts and to recruit citizenry labor to fill the bomb craters as soon as possible after a strike. With nightfall, experienced military repair crews, with materials and equipment, begin the actual repair of ties and rails (FAF Deputy for Intelligence 1952a, 22-23).

The communist side could make progress on railroad restoration and transportation only at night because of the daytime bombings. The USAF intelligence report suggests that restoration personnel belonging to the North Korean and Chinese military forces, as well as numerous civilian laborers, were continuously mobilized for restoration projects, and there were observers at major railroad sections who could quickly locate breaks in the line. This fact was also confirmed by official North Korean and Chinese documents.

The North Korean and Chinese leadership mobilized large numbers of laborers for railroad and train repairs in order to guarantee the transport of supplies that could make or break the war effort. In particular, the Chinese forces conducting military operations in North Korea, where supplies were totally insufficient, had to replenish supplies and equipment almost completely by transport from China. Furthermore, the bombings destroyed major roads and bridges on a large scale so that railroads were critically important once the Chinese military forces entered the war.

On November 6, 1950, the Chinese military forces formed the Logistical Support Unit composed of railroad laborers and began to conduct railroadrelated operations in earnest. In addition, for the effective management of the railroads, China and North Korea rapidly established a unified railroad management system between the two countries. The basic terms of the agreement between the two countries were determined during a Beijing visit by Kim Il Sung in December 1950. The final outcome of the agreement was specified in "Consultation on the Wartime Military Management System for North Korean Railroads" concluded in Beijing by the Chinese and North Korean governments 
on May 4, 1951 (Yang 2002, 604-612).

The two countries clearly defined the wartime railroad management plan and the system of organization. According to the agreement, a North Korean railroad military management department was officially established in Anju in July 1951. Liu Jing from China was appointed the director and political commissar, and Kim Hwang Il and Kim Hwang Tak from North Korea were appointed the deputy directors in charge of railroad transportation management. The railroad management department had five branches (Huichon, Chongju, Sinsongchon, Pyongyang, and Kowon) and approximately 12,000 Chinese were mobilized. In addition, the Front Railroad Transportation Headquarters was also organized in Anju, in November 1951, to oversee railroad repairs and military defensive tasks. During this time, the railroad corps increased to four divisions, and about 52,000 Chinese were sent to North Korea as members of the Chinese labor service corps (ibid., 612).

North Korea and China attempted to overcome railroad destruction through the utilization of manpower on a large scale, recruiting local inhabitants and the Chinese labor service corps, to counter the overwhelming power of the machines of the USAF. According to Hong Xuezhi, a deputy commander of the Chinese military forces, on average 244 laborers per kilometer were working on railroad restoration in "the triangular zone" of Sinanju, Sopo and Kaechon railroads, which was a major rail center in North Korea. In addition, military supplies were transported by truck, wagons, and rickshaws in damaged sections where a train could not pass. A large number of Chinese labor service corps and local inhabitants played an essential role in transporting mass supplies from one train to another (Hong 2008, 368-369).

The vivid testimony of Park Jin Hong, a South Korean who was mobilized for labor in a doha jakeopdae (river-crossing labor unit) as a prisoner of war, described the daily lives of the North Korean inhabitants who lived with reversed nights and days. The doha jakeopdae was a working group that transshipped cargoes transported by one train to another across a river every night using a log bridge installed beside the railroad bridge near a prison camp. According to Park, the residents of the North Korean farming village where he was staying slept in the daytime and worked outside at night. The village was crowded with many people only at night:

A locomotive and a freight train arrived in the middle of the night. The railroad bridge was destroyed so that a train could not pass. The log bridge was also too weak for an engine locomotive to pass. That was why we were needed. We had to work on the loading and unloading only by hand. We transshipped the cargoes in a cart, and five-to-six people pushed the cart across the log bridge to the other side. When we arrived at the other side, we transshipped cargoes to a freight train on standby. Then, we pushed the freight train to the tunnel up to 300 meters away. We worked at night 
and slept in the daytime and repeated this work every day (J.H. Park 2001, 105).

Park said that there were rails on the log bridge during the period of their labor, but the rails were disassembled to avoid bombing in the daytime. The USAF dropped bombs in this area almost every day, but they attacked only railroad bridges and not log bridges. Park Jin Hong said that the North Korean troops fired at the bombers with anti-aircraft guns, but no bombers had ever been shot down.

In this way, the intensive interdiction policy of the USAF represented by Operation Strangle and Operation Saturate was essentially a battle between machines and humans. As the front became fixed and the conflict settled into fierce trench warfare, reminiscent of World War I, a continuing stream of supplies from the rear area became an issue impacting success or failure. In this situation, the UN forces received troops, supplies and weapons from the rear area of South Korea and Japan without serious difficulty, whereas the Chinese and North Korean military forces had to fight fierce battles throughout the rear area due to the USAF bombing. The inhabitants of the rear area were also unable to live ordinary lives. In particular, the fact that a large number of them had to live with reversed nights and days in order to carry on with nighttime railroad restoration and other kinds of labor heavily affected their daily lives. The people in North Korea had to face the fear of death every day during the two-year armistice negotiations and had to endure abnormal daily lives, including living underground and working through the night, until a truce was signed.

\section{Conclusion}

After the war, Kim Il Sung, the leader of North Korea, declared that the war effort had been a success. Regardless of the historical truth, the North Korean government contended that the war had been started by the United States and South Korea when they launched a preemptive attack on the North on June 25, 1950. They also contended that North Korea, which was a newborn and weak Asian nation, bravely fought off the United States, the most powerful nation in the world fresh from its victory in World War II.

However, the harsh reality experienced by the people in North Korea after the war ended made it difficult to define themselves as the victor. According to a document issued by the Soviet Union immediately after the war, approximately 282,000 civilians had been killed by "air strikes" alone-an average of approximately 250 civilians per day (KIMH 2002, 36). When the war ended, in 1953, the cities and villages of North Korea were completely ruined. As mentioned above, when the investigation group of WIDF visited Pyongyang in 1951 they were unable to find any house walls or ceilings intact. General William 
Dean, commander of the U.S. 24th division, who was taken prisoner during the early days of the war and spent a great part of the war in North Korea, wrote in his memoirs: "Most of the towns were just rubble or snowy open spaces, where buildings had been... The little towns, once full of people, were unoccupied shells" (Dean 1954, 272-275). The sweeping destruction of civilian areas in North Korea due to air strikes had been unquestionably extensive.

Since the end of the war the South Korean and U.S. governments have absolutely rejected the point of view that regards North Korea as a victim. In its 2010 final report the Truth and Reconciliation Commission, established by the South Korean government in 2005, evaluated South Korean and North Korean civilian sacrifices due to USAF air strikes:

Regarding the considerable number of lives sacrificed due to the actions of the U.S. armed forces, the Korea Truth and Reconciliation Commission has decided that the Republic of Korea was under general attack at the time of the Korean War and military requirements took precedence over compliance with civilian protection criteria, given that it was an urgent matter of life and death for the nation. Thus, we defined most of the civilian sacrifices as "collateral damage." In other words, it is sad that civilians were sacrificed by the U.S. armed forces, but they were unavoidable sacrifices (TRC 2010, 3).

Shockingly, the Korean government still justifies the sacrifices of South Korean and North Korean civilians due to the USAF bombings by using the term "collateral damage." This perspective is embedded in South Korean society and it is still hard for South Koreans to hold the view that North Korean civilian casualties were war victims.

Now that the Cold War has ended we need to pay attention to the identity of North Korea, which was not only an attacker during the war but also one of its supreme victims. In particular, we need to understand the deep hatred, pain, and fear that North Koreans harbor, formed as a result of experiencing three years of bombardment. Edgar Snow, the renown American journalist who had witnessed the Japanese aerial bombing of Chongqing in 1939, said that air strikes "arouse a completely personal hate that no one can really understand" (Lindqvist 2001, 75). We need to understand the daily lives of North Koreans who endured underground living with reversed days and nights throughout the war and try to comprehend their "completely personal hate" toward those who caused their suffering. The underground space, which was so dark and small for the North Korean civilians, formed the mother's womb that gave birth to a people completely different from who they had been before the war. The basis of peace and reconciliation in East Asia should be sought by looking squarely at this truth. 


\section{Notes}

This work was supported by the National Research Foundation of Korea (NRF) grant funded by the Korean Government (MEST) (NRF-2010-361-A00017).

1. Of course, it's very hard to say that the lives of South Koreans were peaceful during the early months of the Korean War (June-September 1950). South Koreans also suffered from horrible massacres and indiscriminate aerial bombing. See T. Kim 2012a.

2. In this article the Romanization of Korean generally follows these rules: The Revised Romanization of Korean (2000), the official system in South Korea, is used for general terms and document/book titles, and for place names in South Korea. For names of cities/ locations in North Korea, the official North Korean system is used to facilitate location of sites on current maps. For personal names the South Korean system is used unless the Romanized names are cited in documents or are widely accepted spellings (e.g., Kim Il Sung).

3. WIDF was a huge, global organization that boasted 135 million members in 62 countries in October 1951, and the articles of the federation suggested the extermination of fascism and the establishment of permanent peace (Joseon Jung'ang Tongsinsa 1952, 203).

\section{References}

Cumings, Bruce. 2004a. North Korea: Another Country. New York: The New Press.

Cumings, Bruce. 2004b. “Korea: Forgotten Nuclear Threats." Le Monde Diplomatique, December.

Dean, William. 1954. General Dean's Story. New York: Viking Press. http://mondediplo. com/2004/12/08korea (accessed October 31, 2014).

DPRK (Democratic People's Republic of Korea). 1950. "Joseon minjuju-ui inmin gonghwaguk naegak gyeoljeong je175ho" [175th Decision of the Cabinet, Democratic People's Republic of Korea], July 29.

FAF (Fifth Air Force) Deputy for Intelligence. 1952a. "Fifth Air Force Intelligence Summary." January 12. Microfilm Roll No. 49780, Air Force Historical Research Agency (AHRA), Maxwell AFB, Alabama, USA.

FAF Deputy for Intelligence. 1952b. "Fifth Air Force Intelligence Summary, Vol. 2: Effect of UN Rail Interdiction on North Korean Conscripted Labor." February 5. Microfilm Roll No. 49780, AHRA, Maxwell AFB, Alabama, USA.

FAF G-2 Eighth Army and A-2. 1951. "Supply and Transport, CCF and NKPA." September 23. In Futrell 1961, 405.

FAF Operations Analysis Office. 1951a. "Preliminary Report on Investigation of Psychological Effects of Tactical Air Power in Korea." March 25.

FAF Operations Analysis Office. 1951b. "Operations Analysis Office Memorandum, Incidence of Targets in Close Support and Interdiction Attacks." May 21.

FEAF (Far East Air Force). 1951. "Air Force Activities, Korea, 1951, Bombing." NASM 4A, 38544, National Archives and Records Administration, Washington, D.C. 
Futrell, Robert. 1961. “Ten Months of Comprehensive Railway Interdiction.” The United States Air Force in Korea, 1950-1953. New York: Duell, Sloan and Pearce.

Han, Sunghoon. 2012a. Jeonjaeng gwa inmin [War and People]. Seoul: Tolbaeke.

Han, Sunghoon. 2012b. "Gae-in pyeonji-e natanan bukhan inmin-ui jeonjaeng seosa" [Descriptions of War in North Korean Individuals' Letters]. Gyeongje wa Sahoe 94: 339-372.

Hong, Hakji. 2008. Jungguk-i bon hangukjeonjaeng [Chinese Perspectives on the Korean War]. Seoul: Hankuk Haksul Jeongbo.

Joseon Jung'ang Tongsinsa. 1952. Joseon Jung'ang Yeongam, 1951 1952 [Korean Central Almanac, 1951-1952]. Pyongyang: KCPA.

Jung Ilyong. 1950. "Saneopseong jisi je284ho: Jeonsi cheoldo hwamul susong bojang-e gwanhayeo" [284th Order of the Industry Department: About the Wartime Transportation of Rail Freight]. August 17.

Kim, Il Sung. 1980a. "Jeonsisusong-eul seonggwajeok-euro bojanghara” [Let's Guarantee Successful Wartime Transportation]. Kim Il Sung Jeojakjip 7 [Collected Writings of Kim Ilsung7]. Pyongyang: Korean Workers Party Publications.

Kim, Il Sung. 1980b. "Jogukhaebangjeonjaeng-ui seungnireul wihan gak jeongdang gwaeop" [Duties of Each Political Party for Victory in the National Liberation War]. Kim Il Sung Jeojakjip 7 [Collected Writings of Kim Il Sung 7]. Pyongyang: Korean Workers Party Publications.

Kim, Taewoo. 2012a. "War against an Ambiguous Enemy: U.S. Air Force Bombing of South Korean Civilian Areas, June-September 1950." Critical Asian Studies 44 (2): 205-226.

Kim, Taewoo. 2012b. "Limited War, Unlimited Targets: U.S. Air Force Bombing of North Korea during the Korean War, 1950-1953." Critical Asian Studies 44 (3): 467-492.

KIMH (Korea Institute of Military History). 2001. "Soryeon gunsagomundanjang Rajuvayev-ui 6.25jeonjaeng bogoseo 1" [Report on the Korean War Written by Rajuvayev, Head of the Soviet Military Advisory Group 1]. Seoul: KIMH.

KIMH. 2002. "Soryeon gunsagomundanjang Rajuvayev-ui 6.25jeonjaeng bogoseo 3" [Report on the Korean War Written by Rajuvayev, Head of the Soviet Military Advisory Group 3]. Seoul: KIMH.

Kohn, Richard, and Joseph Harahan, eds. 1986. Air Interdiction in World War II, Korea, and Vietnam: An Interview with General Earle E. Partridge, General Jacob E. Smart, and General John W. Vogt, Jr. Washington, D.C.: U.S. Air Force, Office of Air Force History. http://www.afhso.af.mil/shared/media/document/AFD-100525-070.pdf (accessed October 2, 2014).

KWP (Korean Workers Party). 1950. "Joseon nodongdang dangjungang jeongchiwiwonhoe je48cha hoi-ui gyeoljeongseo" [Decisions of the 48th Convention, Central Political Committee, Korean Workers Party]. July 29.

Lindqvist, Sven. 2001. A History of Bombing. New York: The New Press.

Mark, Eduard. 1994. Aerial Interdiction: Air Power and Land Battle in Three American Wars. Washington, D.C.: Office of Air Force History.

NHCC (National History Compilation Committee), ed. 2006. Hangukjeonjaeng, munseo wa jaryo, 1950 53 [The Korean War, Documents and Data, 1950-53]. Seoul: NHCC.

Park, Jin Hong. 2001. Doraon paeja [Return of the Loser]. Seoul: Yeoksa bipyeongsa.

Park, Jongcheol. 2008. "Hanbando cheoldo buseolgwa jegukju-ui-ui gyeongjaeng gwa eummo" [Construction of Railroads in the Korean Peninsula and the Competition 
and Conspiracy of the Imperialists]. In Dong-asia cheoldo network-ui yeoksa wa jungchgyeongjehak 1 [History and Political Economics of the Railroad Network in East Asia 1], ed. Jo Jinku. Seoul: Rebook.

Randolph, Richard, and Ben Mayo. 1952. “The Application of FEAF Efforts in Korea." Staff Study for Deputy for Operations, FEAF, April 12.

Rodong Sinmun. 1950a. August 5.

Rodong Sinmun. 1950b. August 30.

Rodong Sinmun. 1952a. July 8.

Rodong Sinmun. 1952b. August 23.

Rodong Sinmun. 1952c. September 24.

Rodong Sinmun. 1952d. September 29.

Rodong Sinmun. 1952e. November 27.

Shtykov, Terenti. 1950. “Telegram from Shtykov, Soviet Ambassador to North Korea, to Stalin: Political Opinions of North Korea Concerning the Entry into the War of the United States." July 7. In NHCC 2006, 74-75.

Springer, Chris. 2009. North Korea Caught in Time: Images War and Reconstruction. Reading: Garnet Publishing.

Staff of the 315th Military Unit, North Korean Army. 1950. "March-Order." August. Item 51, SA 2010, RG 242. National Archives and Records Administration, Washington, D.C.

Stewart, James, ed. 1957. Air Power-The Decisive Force in Korea. Princeton, NJ: D. Van Nostrand Company.

Suh, Bohyuk. 2008. "Bukhan-ui saneophwa wa cheoldo gundaehwa jeongchaek" [Modernization of North Korea and Railroad Policy]. In Dongasia cheoldo networkui yeoksa wa jeongchigyeongjehak 1 [History and Political economics of the Railroad Network in East Asia 1], ed. Jo Jinku. Seoul: Rebook.

Torkunov, A. V. 2003. Hangukjeonjaeng-ui jinsil gwa susukkekki [Truth and Mystery of the Korean War]. Seoul: Editor.

TRC (Truth and Reconciliation Commission, ROK). 2010. Jinsil hwahae wiwonhoe jonghap bogoseo III [Comprehensive Report, Truth and Reconciliation Commission, ROK III]. Seoul: TRC.

WICIWAK (Womens International Commission for the Investigation of War Atrocities Committed in Korea). 1951. "Report of the Women's International Commission for the Investigation of Atrocities Committed by U.S.A. and Syngman Rhee Troops in Korea." In Korean War Documents Collection 59: The US Department of State Relating to the Internal Affairs of Korea, XXI (1951.7.24-9.5), ed. Korea Institute of Military History 2001. Seoul: KIMH, 354-421.

Yang, Jinsam. 2002. "Jeonjaenggi jungguk jidobu wa bukhan jidobu sa-i-ui mosun kwa galdeung" [Contradictions and Confrontations between Chinese and North Korean Leaders during the Korean War]. In Hangukjeonjaengsa-ui saeroun yeon-gu 2 [New Studies of the History of the Korean War 2], ed. KIMH. Seoul: KIMH.

Taewoo Kim is Humanities Korea Research Professor in the Institute for Peace and Unification Studies, Seoul National University. He received his PhD from Seoul National University (Korean 
History). He received the Kim Chinkyun Award for his book P'okkyeok (Bombing) in February 2014, recognizing his contribution to academia and peacebuilding on the Korean Peninsula. His recent publications include "War against an Ambiguous Enemy: U.S. Air Force Bombing of South Korean Civilian Areas, June-September 1950" (Critical Asian Studies, June 2012) and "Limited War, Unlimited Targets: U.S. Air Force Bombing of North Korea during the Korean War, 1950-1953” (Critical Asian Studies, September 2012). E-mail: peace21@snu.ac.kr 